www.jmscr.igmpublication.org

Impact Factor 5.84

Index Copernicus Value: 71.58

ISSN (e)-2347-176x ISSN (p) 2455-0450

crossref DOI: _https://dx.doi.org/10.18535/jmscr/v5i9.39

Journal Of Medical Science And Clinical Research

\title{
Assessment of Clinical Profile, Bacterial Profile and Outcome of Acute Bacterial Meningitis in A Tertiary Care Hospital
}

\author{
Authors \\ Dr C.J.Selvakumar M.D, D.M (Neuro Medicine) ${ }^{1}$, Dr P.Balamurugan M.D², \\ Dr Shadiya. $\mathbf{C}^{3}$ \\ ${ }^{1}$ Assistant Professor of Neurology, Coimbatore Medical College Hospital, Coimbatore \\ ${ }^{2}$ Assistant Professor of Medicine, Coimbatore Medical College Hospital, Coimbatore \\ ${ }^{3}$ Junior Resident in General Medicine, Coimbatore Medical College Hospital, Coimbatore \\ Corresponding Author \\ Dr P.Balamurugan M.D \\ Assistant Professor of Medicine, Coimbatore Medical College Hospital, Coimbatore
}

\begin{abstract}
Background: Bacterial meningitis is still one of the major causes of mortality and morbidity among all groups in developing countries. The mortality and prevalence of common pathogens has reduced in developing countries with implementation of successful vaccination against the pathogens. Laboratory surveillance of pathogens is crucial in formulating the empirical treatment guidelines and to identify the targets of immunization. The present study was undertaken to evaluate the clinical profile, bacterial pathogens and their antibiotic sensitivity pattern of the pathogens. The outcome of the cases was recorded and followed for six months to detect any neurological sequelae.

Methods: A prospective and cross-sectional study was done and all suspected cases of acute bacterial meningitis (ABM) were screened and confirmed by diagnostic criteria. Clinical features were recorded and entered into the case sheet. CSF culture was done and biochemical analysis and cell counts were performed. All the data was entered in Microsoft excel and analysed.

Results: A total of 400 cases were screened and 272 confirmed with 154 males and 118 females. 268 pathogens were isolated with 256 bacterial and 12 fungal isolates. Gram negative bacterial pathogens were predominant than gram positive. Streptococcus pneumoniae was the common isolate in the study followed by others like S. aureus, Coagulase negative staphylococci and Acinetobacter sp., Escherichia coli, Klebsiella pneumoniae and meningococci. Candida albicans and Cryptococcus sp. were fungal pathogens. Community acquired meningitis was commonest cause and seen in 51-60 years of age. Gram positive pathogens exhibited maximum sensitivity to vancomycin and linezolid whereas Gram negative pathogens to carbapenems.

Conclusions: There is an overwhelming need to formulate policies in the management of cases of ABM. The rationale use of antibiotics is necessary to prevent the development of antibiotic resistance. Hence minimizing the emergence of antibiotic resistance and its spread is necessary, which can be achieved by regular prevalence and antibiotic susceptibility studies.

Keywords: Acinetobacter sp., Acute bacterial meningitis, Antibiotic resistance, Cerebro spinal fluid, Streptococcus pneumonia.
\end{abstract}




\section{INTRODUCTION}

Acute bacterial meningitis (ABM) is one of the leading health conditions causing morbidity and mortality in all age groups. It is usually caused by bacteria, virus, fungi, and parasites. Knowing the etiological agent early helps in appropriate intervention and management with goodprognosis and absence of defects. In developing countries like India despite significant advances in management and intervention, the mortality remains $16-34 \%$. Pathogens responsible for ABM varies from region, time and patient age. Awareness, availability and vaccination coverage influences the prevalence and epidemiological pattern of pathogens of ABM. Studies globally have reported Streptococcus pneumoniae, Meningococci, and Haemophilus influenza as the most common pathogens. However, by the implementation of successful vaccination against the pathogens, the incidence of meningitis by these pathogens has reduced in developed countries. Clinical manifestations and outcome of patients with meningitis are variable depending upon the pathogen. Hence a thorough knowledge about the prevalent pathogen and its prognosis and complication are a must to the physician in management. Laboratory support is imperative in knowing the pathogen. Laboratory surveillance of isolates is essential to identify targets for immunization, to develop strategies and formulate national policies for potential bacterial pathogens. Since the development of antimicrobial resistance is observed it becomes more necessary in the management of meningitis. The present study was done to evaluate the bacterial pathogens of meningitis in adults and to determine their antibiogram. The outcome and prognosis of the patients were also evaluated.

\section{METHODS}

A prospective cross-sectional study was conducted in Department of Neuromedicine at Coimbatore Medical College and Hospital. All the subjects suspected with acute bacterial meningitis $(\mathrm{ABM})$, attending the casualty or OPD were included in the study. The study was done for a period of one year from August 2015 to July 2016. Informed consent was obtained from all the participants or from guardians after explaining the study. The clinical profile, sociodemographic data was collected by interviewing and examining the participants and entered into case sheet. The outcomes of all the included patients were noted as favourable (recovery) and unfavourable which included any neurological defects or other clinical morbidities and mortality.

Diagnostic criteria for acute bacterial meningitis

- Positive culture with or without a positive gram stain. $\cdot$ CSF cell count $>10$ cells $/ \mathrm{mm} 3$ with predominant polymorphonuclear Neutrophils. - CSF protein $>45 \mathrm{mg} \%$. $\cdot$ CSF glucose $<40 \mathrm{mg} \%$.

\section{Inclusion criteria}

Patients above 18 years of age with symptom and signs of meningitis (fever, severe headache, vomiting, altered mental status, photophobia, neck stiffness, and Kerning's, Brudziniski signs) were included in the study. The CSF sample was collected from the patients by lumbar puncture under aseptic conditions and transported to the clinical microbiology laboratory for processing in asterile leak-proof container. The specimen was processed immediately.

The macroscopic appearance of CSF sample was noted, hemorrhagic and inadequate sample $(<2 \mathrm{ml})$ was not processed. The sample was divided into three portions and one was centrifuged at 1000 rpm for 15 minutes and deposit used for, Gram staining, $\mathrm{Zn}$ staining and negative staining with Indian ink. The 2 nd portion was inoculated on sheep blood agar, MacConkey agar, and chocolate agar, also on Sabourads dextrose agar for fungal growth. All the culture plates were incubated in $\mathrm{CO} 2$ incubator at $37^{\circ} \mathrm{C}$ with $5 \% \mathrm{Co} 2$. All the media were inspected for growth up to 72 hours. Routine CSF cell count, glucose, and protein estimation were done on 3rd portion. Growth on media plates was identified by standard biochemical tests and antibiotic susceptibility test was done by modified Kirby-Bauer disk diffusion method and interpreted in accordance with CLISI guidelines. 


\section{Exclusion criteria}

All the cases which were culture negative and not fulfilling the criteria of meningitis by CSF cell counts or other parameters (raised protein, hypoglycorrhachia) were excluded from the study.

\section{RESULTS}

During the study period of one year, a total of 400 cases suspected with bacterial meningitis were screened. Out of 400 cases, only 272 cases were diagnosed as ABM based on inclusion criteria. Out of 272, $154(56.16 \%)$ were males and 118 (43.84\%) were females. The most common age group in the study was 51-60 years $(25.18 \%)$ followed in order by 61-70 years $(22.34 \%), 4150$ years $(18.79 \%),>70$ years $(14.18 \%)$ and least among 20-30 years $(6.38 \%)$. Most of the cases $(50.35 \%)$ were community acquired whereas others post-surgical (17.02\%), traumatic $(21.28 \%)$ and nosocomial $(11.35 \%)$. Table 2 explains the distribution of cause of meningitis among different age groups. Community-acquired and nosocomial were more common at 51-60 years and traumatic and post-surgical were common at 61-70 years. Headache was the commonest symptom (97\%) followed by fever (94\%), vomiting (93\%), 49\% complained of photophobia, seizures in $19 \%$, altered mental status in $43 \%$, Neck stiffness in 39\%, Kernig's sign (11\%) and Brudziniski sign in 14\% were observed (Figure 1). The patients were managed as per the guidelines and followed till recovery and further for six months for any defect or morbidity. 93.62\% (264 cases) had favorable outcome without any defects and $6.38 \%$ (18 cases) had an unfavourable outcome. 6 cases expired out of which 4 were HIV positive and 2 had septicaemia with multiorgan failure, 7 cases developed partial deafness and 5 had paresis of right upper limb (Table 1).

\section{Laboratory analysis of CSF parameters}

$43.26 \%$ of cases had cell counts with 10-100 cells $/ \mathrm{mm} 3$ and $56.74 \%$ had $>100$ cells $/ \mathrm{mm} 3$. CSF glucose $<20 \mathrm{mg} \%$ was observed in $40.43 \%$ and 21 $40 \mathrm{mg} \%$ in $59.57 \%$. CSF protein $>90 \mathrm{mg} \%$ in $70.21 \%$ cases and $45-90 \mathrm{mg} \%$ in $29.79 \%$ cases were observed (Table 1).
CSF gram stain and culture were done. Out of 282 culture positive CSF specimens, gram stain positivity was seen in $36.88 \%$ (104 cases). Gramnegative bacteria were predominant 134 (47.52\%) followed by gram positive $132(46.81 \%)$ and fungi $12(5.67 \%)$. Streptococcus pneumoniae was the major pathogen in the study $(19.15 \%)$ followed by Staphylococcus aureus (16.31\%), Acinetobacter sp. (12.06\%), coagulase negative staphylococcus $(11.35 \%)$, Escherichia coli and meningococci (9.93\%) and Pseudomonas sp. and Klebsiella pneumoniae $(7.8 \%)$ in the study. Candida albicans and Cryptococcus accounted for 5.67\%.

Antibiotic sensitivity was done by Modified Kirby-Bauer disk diffusion method and results were interpreted. Gramnegative isolates exhibited resistance towards commonly used antibiotics and maximum sensitivity was seen to imipenem, meropenem, and piperacillin + tazobactam. Among gram-positive bacteria maximum sensitivity was observed to vancomycin and linezolid (Table 3 and 4).

Table 1: Clinical, socio demographic profile of cases.

Table 1: Clinical, socio demographic profile of cases.

\begin{tabular}{|c|c|c|c|}
\hline Parameter & Variable & Number & $\%$ \\
\hline \multirow{2}{*}{ Gender } & Male & 164 & 58.16 \\
\hline & Female & 118 & 41.84 \\
\hline \multirow{6}{*}{ Age } & $20-30$ years & 18 & 6.38 \\
\hline & $31-40$ years & 37 & 13.12 \\
\hline & $41-50$ years & 53 & 18.79 \\
\hline & $51-60$ years & 71 & 25.18 \\
\hline & $61-70$ years & 63 & 22.34 \\
\hline & $>70$ years & 40 & 14.18 \\
\hline \multirow{4}{*}{ Cause } & Community & 142 & 50.35 \\
\hline & Nosocomial & 32 & 11.35 \\
\hline & Traumatic & 60 & 21.28 \\
\hline & Post-surgical & 48 & 17.02 \\
\hline \multirow{9}{*}{$\begin{array}{l}\text { Signs and } \\
\text { symptoms }\end{array}$} & Fever & 188 & 94 \\
\hline & Headache & 194 & 97 \\
\hline & Vomiting & 186 & 93 \\
\hline & Photophobia & 98 & 49 \\
\hline & Seizures & 38 & 19 \\
\hline & $\begin{array}{l}\text { Altered mental } \\
\text { status }\end{array}$ & 86 & 43 \\
\hline & Neck stiffness & 78 & 39 \\
\hline & Kernigs sign & 22 & 11 \\
\hline & Brudzinski sign & 28 & 14 \\
\hline \multirow{2}{*}{$\begin{array}{l}\text { Outcome of } \\
\text { the case }\end{array}$} & Favourable & 264 & 93.62 \\
\hline & Unfavourable & 18 & 6.38 \\
\hline \multicolumn{4}{|c|}{ Laboratory parameters of CSF } \\
\hline \multirow{2}{*}{$\begin{array}{l}\text { CSF cell } \\
\text { count }\end{array}$} & $10-100$ cells $/ \mathrm{mm}^{3}$ & 122 & 43.26 \\
\hline & $>100$ cells $/ \mathrm{mm}^{3}$ & 160 & 56.74 \\
\hline \multirow{2}{*}{ CSF glucose } & $<21-40 \mathrm{mg} \%$ & 168 & 59.57 \\
\hline & $<20 \mathrm{mg} \%$ & 114 & 40.43 \\
\hline \multirow{2}{*}{ CSF protein } & $45-90 \mathrm{mg} \%$ & 84 & 29.79 \\
\hline & $>90 \mathrm{mg} \%$ & 198 & 70.21 \\
\hline
\end{tabular}


Figure 1: Clinical signs and symptoms

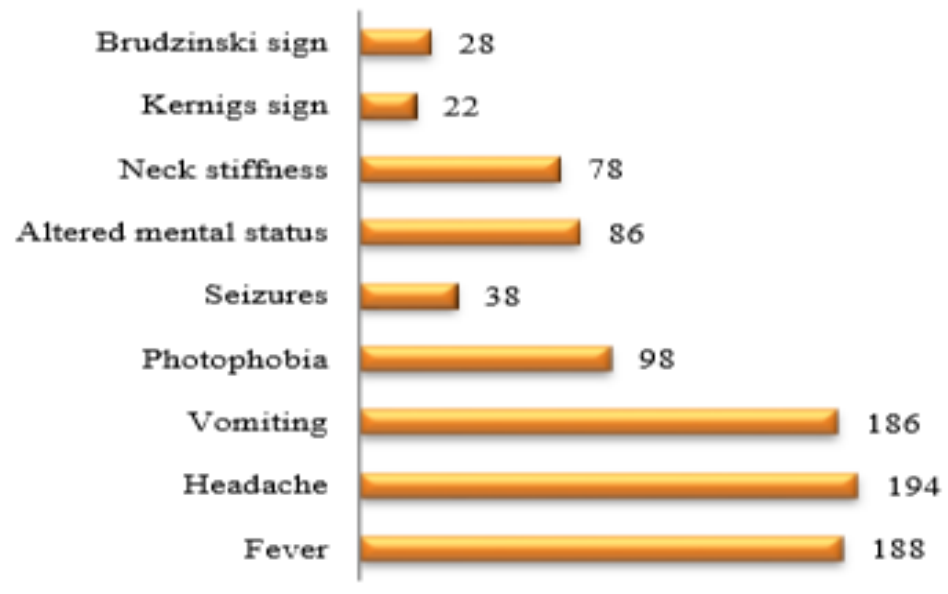

Table 2: Distribution of meningitis and cause in different age groups.

\begin{tabular}{|llllllll|} 
& $\begin{array}{l}\mathbf{2 0 - 3 0} \\
\text { years }\end{array}$ & $\begin{array}{l}\mathbf{3 1 - 4 0} \\
\text { years }\end{array}$ & $\begin{array}{l}\mathbf{4 1 - 5 0} \\
\text { years }\end{array}$ & $\begin{array}{l}\mathbf{5 1 - 6 0} \\
\text { years }\end{array}$ & $\begin{array}{l}\mathbf{6 1 - 7 0} \\
\text { years }\end{array}$ & $\mathbf{7 0 \text { years }}$ & Total \\
\hline Community & $\mathbf{8}$ & $\mathbf{2 3}$ & 38 & 53 & 10 & 10 & 142 \\
\hline Nosocomial & 2 & 5 & 3 & 11 & 6 & 5 & 32 \\
\hline Traumatic & 5 & 7 & 7 & 2 & 28 & 11 & 60 \\
\hline Post-surgical & 3 & 2 & 5 & 5 & 19 & 14 & 48 \\
\hline Total & $\mathbf{1 8}$ & $\mathbf{3 7}$ & $\mathbf{5 3}$ & $\mathbf{7 1}$ & $\mathbf{6 3}$ & $\mathbf{4 0}$ & $\mathbf{2 8 2}$ \\
\hline
\end{tabular}

Table 3: Antibiotic sensitivity of gram negative bacterial isolates from CSF (\%).

\begin{tabular}{|llllll|}
\hline Antibiotic & $\begin{array}{l}\text { Escherichia } \\
\text { coli }(\mathbf{n = 2 8})\end{array}$ & $\begin{array}{l}\text { Acinetobacter sp. } \\
(\mathbf{n = 3 4 )}\end{array}$ & $\begin{array}{l}\text { Pseudomonas } \\
\text { sp. }(\mathbf{n = 2 2})\end{array}$ & $\begin{array}{l}\text { Klebsiella } \\
\text { pneumoniae } \mathbf{( n = 2 2 )})\end{array}$ & $\begin{array}{l}\text { Meningococci } \\
(\mathbf{n = 2 8})\end{array}$ \\
\hline Pencillin & NT & NT & NT & NT & NT \\
\hline Piperacillin & NT & NT & 82 & NT & 86 \\
\hline Gentamycin & 88 & 86 & 84 & 88 & 92 \\
\hline Amikacin & 90 & 88 & 88 & 90 & 88 \\
\hline Ceftriaxone & 82 & 86 & NT & 92 & NT \\
\hline Cefotaxim & 78 & 88 & NT & 88 & NT \\
\hline Cefixime & 88 & 92 & 84 & 88 & NT \\
\hline Ceftazidime & 82 & 90 & NT & 82 & 92 \\
\hline $\begin{array}{l}\text { Amoxycillin }+ \\
\text { clavulanic acid }\end{array}$ & 88 & NT & 94 & NT & NT \\
\hline $\begin{array}{l}\text { Piperacillin+ } \\
\text { tazobactam }\end{array}$ & NT & 88 & 100 & 100 & 100 \\
\hline Imipenem & 98 & 100 & 100 & 100 & 100 \\
\hline Meropenem & 100 & 100 & 98 & 90 & NT \\
\hline Polymyxin-B & 91 & 90 & & & \\
\hline
\end{tabular}

*NT- Not tested.

Table 4: Antibiotic sensitivity of Gram positive bacterial isolates from CSF (\%).

\begin{tabular}{|l|l|l|l|}
\hline Antibiotics & Streptococcus preumoniae $(\mathrm{n}=\mathbf{5 4})$ & Staphylococcus aureus $(\mathbf{n}=\mathbf{4 6})$ & CONS $(\mathbf{n}=\mathbf{3 2})$ \\
\hline Pencillin & 100 & 68 & 76 \\
\hline Oxacillin & NT & 88 & 92 \\
\hline Cefoxitin & 94 & 92 & 88 \\
\hline Ceftriaxone & 94 & 86 & 84 \\
\hline Vancomycin & 100 & 100 & 100 \\
\hline Linezolid & 100 & 100 & 100 \\
\hline
\end{tabular}




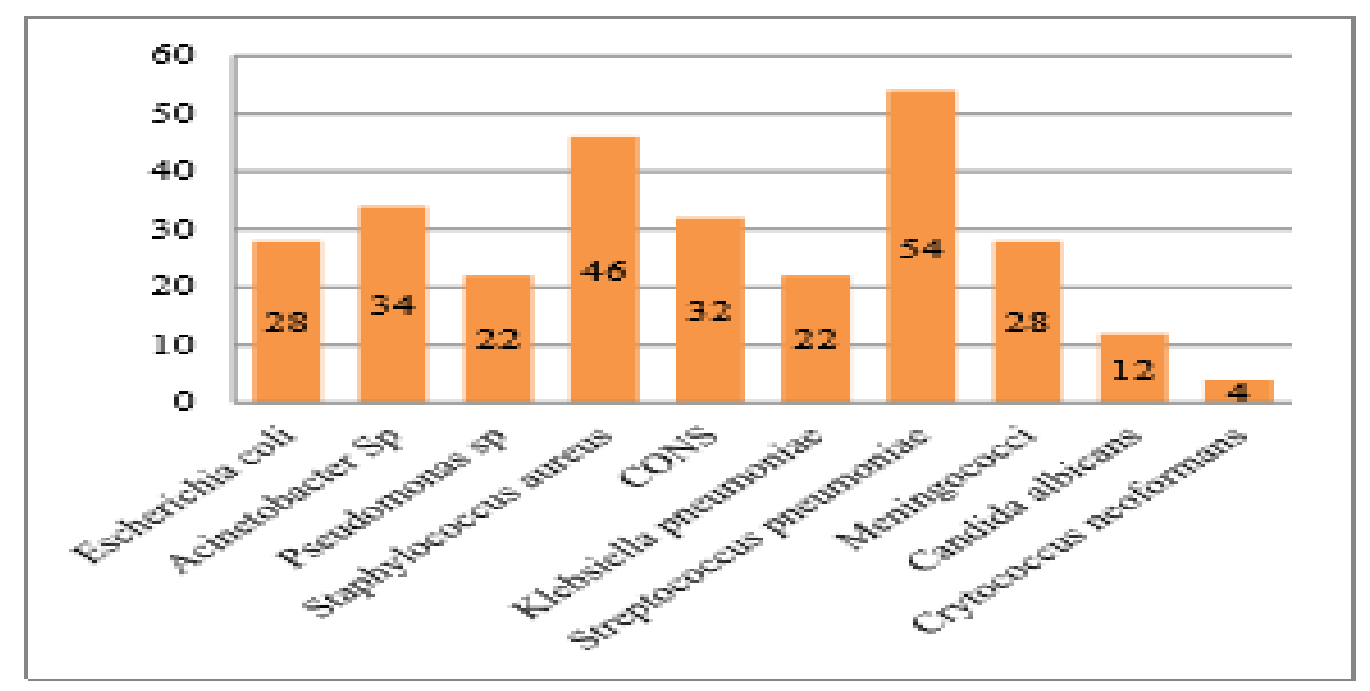

Figure 2: Isolates from the CSF.

\section{DISCUSSION}

Bacterial meningitis is an inflammation of the meninges and the underlying subarachnoid CSF. Acute bacterial meningitis is a medical emergency requiring immediate management. The choice of antibiotic depends on the isolate prevalent in the region, its antimicrobial susceptibility pattern and the age of the patient. Laboratory investigations of CSF specimens are extremely important in diagnosing and management of patients.

Most studies reported Grams staining as an appropriate single test for identifying bacteria in CSF specimens. In present study, the CSF positivity by gram staining was $36.88 \%$. However, various studies reported a gram stain sensitivity ranging from $30-60 \%$ and high specificity of $>97 \%$.

In present study, $\mathrm{ABM}$ was more in males than females and the male to female ratio was 1.4:1. This finding is in par with findings of studies of Singh AK et al, Manjiyil IJ et al.13,14 The most common age group observed in the study was 5160 years, and community-acquired was the commonest cause of meningitis in present study. This is variable from place to place based on the age, prevalent predominant pathogen, and multiple factors. In present study, an exceptional finding was the traumatic cause of ABM was most common in 61-70 years age group. The reason could not be explained.
Headache was the most common symptom followed by fever, vomiting, and photophobia. Episodes of seizures were seen in $19 \%$ of cases, many studies reported less incidence of seizures in adults when compared to pediatric age. Findings of Sudharshan Reddy RC et al, Bareja et al reported a high incidence of seizures $>38 \%$ in children and adults.15,16 Altered mental status, neck stiffness and Neurological signs Kernings sign and Brudzniski's sign were observed and found similar with other studies.17 Laboratory parameters were on par with many studies with neutrophilic pleocytosis in all cases of ABM, raised protein and reduced glucose levels.

Among the gram-negative pathogens, Acinetobacter sp. remained high and was resistant to most common antibiotics. There has been a significant increase in the number of Acinetobacter as a major pathogen in immunocompromised conditions. Carbapenems exhibited maximum sensitivity towards a majority of gramnegative pathogens in the study. Cephalosporins tested exhibited second best activity against gramnegativepathogens and Piperacillin/tazobactam exhibited good sensitivity to Pseudomonas sp.

\section{CONCLUSION}

To conclude, there is an overwhelming need to formulate policies in the management of cases of $\mathrm{ABM}$. The rationale use of antibiotics is necessary 
to prevent the development of antibiotic resistance. Hence minimizing the emergence of antibiotic resistance and its spread is necessary, which can be achieved by Regular prevalence and antibiotic susceptibility studies. This would also be helpful for clinicians choosing an appropriate empirical antimicrobial rationale.

\section{REFERENCES}

1. Kabra SK, Kumar P, Verma IC, Mukherjee D, Chowdhary BH, Sengupta $S$, et al. Bacterial meningitis in India: An IJP survey. Indian J Pediatr 1991;58:50511.

2. Chinchankar N, Mane M, Bhave S, Bapat S, Bavdekar A, Pandit A, et al. Diagnosis and outcome of acute bacterial meningitis in early childhood. Indian Pediatr. 2002;39:914-21.

3. Mani R, Pradhan S, Nagarathna S, Wasiulla R, Chandramuki A. Bacteriological profile of community acquired acute bacterial meningitis a tenyear retrospective study in a tertiary neuro care centre in south India. Indian $\mathrm{J}$ Med Microbiol. 2007;25(2):108-14.

4. Nabi G, Kahn TA, Raj AB. Bacterial meningitis in children. Saudi Med J. 1992;13:348-51.

5. Clinical Laboratory Standard Institute. 2014. Performance standard for antimicrobial disk susceptibility tests. Approved standard-20th Ed. Supplement/ M2-A9 2006:26(1)

6. Antimicrobial chemotherapy. In: Jawetz, Melnick, Adelberg's Medical Microbiology. 21st Ed. International Edition, Stanford, Connecticut, Prentice-Hall International Inc:

7. Elmore JG, Horwitz RI, Quagliarello VJ. Acute meningitis with a negative Gram's stain: Clinical and management outcomes in 171 episodes. Am J Med. 1996;100:7884.

8. Durand ML, Calderwood SB, Weber DJ, Miller SI, Southwick FS, Caviness VS Jr, et al. Acute bacterial meningitis in adults. A review of 493 episodes. N Engl J Med. 1993;328:21-

9. Modi S, Anand AK. Phenotypic Characterization and antibiogram of CSF isolates in acute bacterial meningitis. J Clin Diagost Res. 2013;7(12):2704-8.

.

